\title{
Cloud-Based Collaborative Writing to Develop EFL Students'Writing Quantity and Quality
}

\author{
Samah Zakareya Ahmad ${ }^{1}$ \\ ${ }^{1}$ Faculty of Education, Suez University, Suez, Egypt \\ Correspondence: Samah Zakareya Ahmad, Faculty of Education, Suez University, Suez, Egypt.
}

Received: November 28, 2019

Accepted: January 12, 2020

Online Published: February 18, 2020

doi:10.5539/ies.v13n3p51

URL: https://doi.org/10.5539/ies.v13n3p51

\begin{abstract}
This study has devoted itself to examining the effect of using cloud-based collaborative writing on EFL students' writing quantity and quality. Twenty-one EFL students studying at Jubail College of Education, IAU University participated in the study. They were pretested in writing quantity and quality before the treatment then they practiced cloud-based collaborative writing for a whole semester before being posttested in both measures. Results from non-parametric Wilcoxon Signed Ranks revealed no significant difference between the pretest and the posttest regarding writing quantity whereas it revealed a significant difference with regard to writing quality. It was concluded that cloud-based collaborative writing can be used to improve the quality of essays written by EFL students. Recommendations and research suggestions were introduced.
\end{abstract}

Keywords: cloud-based collaborative writing, EFL students, writing quantity, writing quality

\section{Introduction}

\subsection{Problem of the Study}

English in Saudi Arabia is essential to the economic, social, and religious domains (Al-Asmari, 2013; Al-Rabai, 2016; Al-Rashidi \& Phan, 2015; Faruk, 2013). There is also an increasing endeavor of Saudi Arabian students to learn English due to the strong need for English language skills in the Saudi job market (Al-Saraj, 2014). English writing skills are critical to educational and occupational success (Togatorop, 2015). Some researchers go even further to consider them as essential capabilities for surviving in the $21^{\text {st }}$ century (Rosário et al., 2017; Yeh, Lo, \& Huang, 2011). However, writing in EFL is a difficult and challenging process (Al-Samadani, 2010; National Assessment of Educational Progress, 2011; Warschauer, 2010) that requires hard work from writers to coordinate a number of cognitive and knowledge skills (Crossley \& McNamara, 2016). Therefore, many students do not possess adequate EFL writing skills (Erkan \& Saban, 2011; Grami, 2010), which may negatively affect their academic achievement (Al-Asmari, 2013). Saudi students are no exception to the rule and their poor EFL writing has been widely reported in many studies (e.g., Al-Khairy, 2013; Al-Mansour \& Al-Shorman, 2014; Grami, 2010; Jahin, 2012; Javid, Farooq, \& Umer, 2013; Khan, 2011; Mahmoud, 2014). For example, Grami (2010) reported the results of the IELTS test for Saudi students that showed that the lowest mean score Saudi students received was in their writing (the average in writing skills was 4.83 out of 9). Moreover, students at Saudi universities believe writing to be the most difficult component of all English language skills (Al-Mansour \& Al-Shorman, 2014; Jahin, 2012).

Through the researcher's experience as an associate professor of TEFL at Jubail College of Education, IAU University, she noticed that writing is indeed a problematic area for most EFL students and that most students get low grades in their writing exams. Furthermore, she administered a writing test to a group of these students. Through analyzing their answers, the researcher found that they wrote insufficiently and she discovered that they committed many errors in coherence, grammar, spelling, structure, word choice, punctuation, phoneme clusters, and use of prefixes and suffixes. Therefore, the need arose to search for a solution for Saudi EFL students' inability to write effectively regarding both quantity and quality. Based on the researcher's search for effective strategies that can improve EFL writing quantity and quality, cloud-based collaborative writing seemed as a promising one.

\subsection{Literature Review}

\subsubsection{Collaborative Learning}

Collaborative learning is needed in today's globally linked world (Lee, 2010) and the application of collaborative 
practices in language classrooms has long been valued (Liou \& Lee, 2013). Cooperation and collaboration are different in the sense that in a cooperative approach, a task is divided among group members and each member works on his/her own part. Finally, the different parts are put together to form a cohesive product. However, in a collaborative process, each member participates in the production of all parts of the product, thereby taking responsibility for the entire work (Schoor, Narciss, \& Körndle, 2015). Collaborative learning offers benefits beyond traditional education. For example, it contributes to developing different skills such as problem solving (Hanko, 2016), active learning (Kloepper, 2017), social skills (Apple, Reis-Bergan, Adams, \& Saunders, 2011), and teamwork skills (Dooley \& Sexton-Finck, 2017). Therefore, collaboration is highly important for both academic and career excellence (Yim \& Warschauer, 2017).

\subsubsection{Collaborative Writing}

Collaborative writing is a specialized form of collaborative learning that involves pairs or small groups of learners in a negotiated decision-making process as well as a substantive interaction in the target language to produce a jointly written text (Dobao, 2012). It can be viewed as a process of negotiation among a group of writers for making the content of a single text (Ansarimoghaddam \& Bee, 2013). It involves a broad range of group activities that result in collective cognition related to language learning in addition to shared responsibility for producing a written product (Storch, 2013). Collaborative writing entails a variety of features. It includes multiple roles, subtasks, and activities (Fung, 2010) where writers come together to share knowledge and choose their language carefully as they construct content (Storch, 2011). It is also characterized by mutual interaction, sharing of expertise, negotiation, repetition, and affective factor (Fung, 2010). Moreover, it implicates active involvement of group members, shared editing, group writing techniques, peer-review, and reflection on written products (Hadjerrouit, 2011).

Collaborative writing is particularly important in academic settings (Yim \& Warschauer, 2017) as it improves writing skills (Mulligan \& Garofalo, 2011), interactional skills (Ramírez, 2013), and sense of ownership (Storch, 2011). Moreover, it drives learners to discuss and reflect on their language to find solutions for the linguistic problems they face (Dobao, 2012) and helps them enhance the organization, content, and vocabulary of their written products (Shehadeh, 2011). Additionally, through writing collaboratively, writers take responsibility for the text they produce and create new ideas and more effective documents (Dobao, 2012). However, some researchers claim that collaboration is often hindered because of the limitations of space and time (Bower \& Richards, 2006). Therefore, a technological component has been recently added to collaborative writing to overcome such an obstacle.

\subsubsection{Cloud-Based Collaborative Writing (CBCW)}

The Internet has become learners' new world where most of their interactions take place (Ramírez, 2013). Cloud-based technology is one of the significant tools of web communications (Limbu, 2012) employing the Internet and enormous remote servers to save files, software, and applications so that mobile devices or computers can reach (Lin, Yu, \& Wang, 2014). Low cost, convenient interface, accessibility, sharing features, and most importantly, a higher efficiency in supporting collaboration (Yim, Warschauer, Zheng, \& Lawrence, 2014) are all potential affordances that make cloud-based technologies more attractive than traditional learning environments (Smith \& Caruso, 2010). Cloud-based technologies do not only act as a means for collaboration, but as an essential component of collaboration (Zhou, Simpson, \& Domizi, 2012). Therefore, educators are turning their attention to cloud computing technologies to enhance collaboration (Al-Cattan, 2014; Guoli \& Wanjun, 2010), facilitate communication (Al-Samarraie \& Saeed, 2018), and support knowledge sharing among learners (Chu \& Kennedy, 2011; Lin et al., 2014). Consequently, it is largely expected that in the near future, cloud tools will have a significant impact on education, enabling both learners and teachers to do their work effectively with less cost (Zurita, Baloian, \& Frez, 2014). The collaborative potential of cloud tools and the widespread availability of social software in L2 teaching have brought a renewed attention to collaborative writing (Li \& Kim, 2016; Liou \& Lee, 2013; Liu, Liu, \& Liu, 2018; Wang, 2016; Yim \& Warschauer, 2017). Therefore, cloud-based collaborative writing (henceforth $\mathrm{CBCW}$ ) is viewed as a means to integrate technology into writing instruction (Yim et al., 2014) through facilitating content construction (Elola \& Oskoz, 2010) and enhancing learner-to-learner writing (Strobl, 2015).

\subsubsection{Benefits of CBCW}

Research suggests that $\mathrm{CBCW}$ is particularly beneficial for $\mathrm{L} 2$ student writers as it provides them with new opportunities to participate in writing and show the texts they created in a nonthreatening atmosphere (Yim et al., 2014) with little limitation on time and space (Yim \& Warschauer, 2019). In this way, writers will have the opportunity to collaborate as well as share and develop their writing techniques (Limbu, 2012). Therefore, with 
CBCW, writing becomes more vibrant, visible, and dynamic (Warschauer, 2011) as writers can view, comment on, and modify their texts any time and from anywhere (Limbu, 2012). That is why Calvo, O'Rourke, Jones, Yacef, and Reimann (2011) suppose that cloud-based technologies are likely to change the way people write together.

\subsubsection{Theoretical Basis of $\mathrm{CBCW}$}

The theoretical basis of $\mathrm{CBCW}$ largely relies on three theories: the Sociocultural Theory, Social Presence, and Connectivisim. CBCW rests upon the Sociocultural Theory, put by Lev Vygotsky, which focuses on the role of social interaction in learning and conceptualizes learning as a socially situated activity (Vygotsky, 1978). According to this theory, learners have a critical effect on each other's learning when working together as they can assist each other to make their performance better than the competence level they can reach individually (Storch, 2013). Therefore, it focuses on the role of collaboration in the development of L2 (Dobao, 2012). Unlike the traditional process of writing, which focuses on individual production, the nonlinear approach to process writing in $\mathrm{CBCW}$ involves collaborative interaction grounded in the sociocultural paradigm of language learning (Lee, 2010). As a result, engaging learners in CBCW can become a means to promote social interaction among them (Fung, 2010). The use of CBCW also draws from the Social Presence Theory developed by Short, Williams, and Christie (1976) which emphasizes how people represent themselves on the Internet (Dixson, 2016). It explains how individuals form relationships over the web and how important these relationships are to their lives (Wei, Seedorf, Lowry, Thum, \& Schulze, 2017). Social presence is an essential component of CBCW (Remesal \& Colomina, 2013) as it reflects the ability of participants to create interpersonal relationships, communicate in an online environment, and show their individual personalities (Garrison, 2009). Another theoretical foundation for $\mathrm{CBCW}$ is the Connectivism Theory offered by George Siemens and Stephen Downes (Ozturk, 2015). Some researchers consider it as a development of constructivism in response to the intense use of technology in education (e.g., Al-Zain, 2019) while others consider it as the base of collaborative e-learning (Mattar, 2018; Vas, Weber, \& Gkoumas, 2018). Connectivism is a conceptual framework which places networked or social learning at the core of instruction (Duke, Harper, \& Johnston, 2013). Connectivist theorists suggest that learning is not only an internal construction of knowledge (Al-Dahdouh, Osorio, \& Caires, 2015) but also the knowledge activated by learners through participating in a learning group (Goldie, 2016). According to connectivism, learning depends on variety of viewpoints and the purpose of connectivist learning activities is to integrate different accurate, specialized, up-to-date information sources to help in problem solving and decision making (Rank, 2018).

\subsubsection{CBCW Technologies}

Many technological tools and applications can be used for CBCW. These include: online word processors (Kessler, Bikowski, \& Boggs, 2012), chats (Elola \& Oskoz, 2010), blogs (Sun \& Chang, 2012), wikis (Aydin \& Yildiz, 2014), and other similar tools like EtherPad and Google Docs (Brodahl, Hadjerrouit, \& Hansen, 2011). These technologies provide writers with various advantages such as the possibility to write at any time and place in addition to access to former versions of the text (Bikowski \& Vithanage, 2016). Moreover, they offer a shared group interface that enables different group members to work together on different parts of the text without conflict (Abrams, 2019). They also facilitate feedback and revision and allow a faster response time (Kessler et al., 2012).

\subsubsection{CBCW and Writing Quantity and Quality}

Some studies found a positive effect for CBCW on writing quantity (e.g., Daskalogiannaki, 2012; Doult \& Walker, 2014; Mak \& Coniam, 2008; Mills \& Exley, 2014; Myers, 2014; Storch, 2011; Yim, Wang, Olson, Vu, \& Warschauer, 2017) and quality (e.g., Abrams, 2019; Al-Shumaimeri, 2011; Arslan \& Şahin-Kizil, 2010; Bailey \& Judd, 2018; Beltrán, 2010; Daskalogiannaki, 2012; Dobao, 2012; Doult \& Walker, 2014; Kessler \& Bikowski, 2010; Mak \& Coniam, 2008; McDonough \& García-Fuentes, 2015; Myers, 2014; Shukor \& Noordin, 2014; Strobl, 2014; Togatorop, 2015; Villarreal \& Gil-Sarratea, 2019; Wichadee, 2011; Yeh, 2014; Yim et al., 2017). Therefore, the researcher decided to investigate the effect of $\mathrm{CBCW}$ on both the quantity and quality of EFL students' writing.

\subsection{Hypotheses}

1) A statistically significant difference would be found between the mean scores of participants between the pretest and the posttest of writing quantity.

2) A statistically significant difference would be found between the mean scores of participants between the pretest and the posttest of writing quality. 


\section{Method}

\subsection{Design}

A one-group pre-posttest design was employed in the present study. A group of English-major undergraduates were pretested on writing quantity and quality before the treatment and posttested after it. Differences between the two measurements were evaluated for statistical significance.

\subsection{Participants}

The present study was conducted at Jubail College of Education, IAU University, with 21 learners of EFL, enrolled in a fifth-level language class, Advanced Essay. All of the participants were female and they spent at least 7 years learning EFL. All participants were familiar with the use of smart phones and computers as they normally use a learning management system (BlackBoard) in in their course of study.

\subsection{Variables}

The study included three variables: one independent $(\mathrm{CBCW})$ and two dependent variables (writing quantity \& writing quality). Operational definitions of these variables can be read below:

\subsubsection{CBCW}

$\mathrm{CBCW}$ is a process of social negotiation among a small group of EFL writers to produce a jointly written text through working together on a Google Docs file from different locations both synchronously and asynchronously. This process includes three stages: preparation, collaborative writing (pre-writing, drafting, \& rewriting), and reflecting.

\subsubsection{Writing Quantity}

Writing quantity is the total number of words in an essay written by an EFL student writer in response to an argumentative essay prompt.

\subsubsection{Writing Quality}

Writing quality is the production of argumentative English essays that include relevant, clear, coherent, and organized ideas with correct grammar, spelling, word choice, and punctuation.

\subsection{Instrument}

An essay writing test was prepared by the researcher to be used as both a pretest and posttest. It consisted of an essay-writing question which required participants to write an argumentative essay of as many words as they could on one of three assigned topics. The researcher sent the test to five TEFL specialists to get it reviewed. Their feedback was taken into consideration. As for reliability, the test was performed twice by a group of EFL students with a two-week's interval to ensure that students would not recall their answers from the first administration. Pearson's Coefficient of correlation between the two administrations was 0.94, significant at the 0.01 level.

\subsection{Scoring}

Students' essays were scored in two different ways: quantitatively and qualitatively. As for writing quantity, students' total words written (TWW) was used; i.e., the total number of legible words in each essay was counted, including incorrectly spelled words (Kormos, 2011; Révész, Kourtali, \& Mazgutova, 2017). McMaster and Campbell (2007) proved that TWW has adequate reliability as they found reliability to range between 0.60 and 0.76. Moreover, Jewell and Malecki (2005) proved TWW's criterion validity when they correlated it with the Stanford Achievement Test. As for writing quality, a rubric was devised by the researcher to be used in scoring participants' essays. In this rubric, 40 points were divided among eight components: relevance, clarity, coherence, organization, grammar, spelling, word choice, and punctuation. Each component has three levels: outstanding (5 scores), developing (3 scores), and weak (1 score).

In order to prevent the possibility of the researcher's bias, three EFL lecturers were assigned to grade the writing test. They have already taught the Advanced Essay course at least once. Inter-scorer reliability was calculated to ensure accuracy of scoring. It was calculated using Pearson's Coefficient of correlation between each two scorers. The correlation coefficient between the first and second scorers' estimations was 0.81 for quantity and 0.87 for quality, between the second and third scorers' estimations was 0.90 for quantity and 0.84 for quality, and between the first and third scorers' estimations was 0.79 for quantity and 0.82 for quality. Based on these calculations and on McGerald and Nidds's (1997) assertion that reliability coefficients are usually 0.70 or higher for standardized assessment in writing, it can be said that the writing test had inter-scorer reliability for both writing quantity and quality. Therefore, each participant's essay was scored independently by each of the three scorers and the average became the final score of the student. 


\subsection{Procedures}

The procedures of the current study were carried out at Jubail College of Education, IAU University during the first term of the academic year 2018/2019 as part of the regular coursework of the Advanced Essay course. Procedures lasted 14 weeks and involved three phases: pretesting, treatment, and posttesting. As for pretesting and posttesting, the writing performance test was administered to all participants before and after the treatment respectively. Concerning the treatment, participants used $\mathrm{CBCW}$ where they used Google Docs, a free online word processing application. Although many $\mathrm{CBCW}$ applications were available (e.g., web-based word processors, Etherpad, Adobe Creative Cloud, Dropbox, Microsoft Windows Live, etc.), Google Docs was selected to be used in the present study for many reasons. First, Google Docs is a promising collaboration tool as it supports both synchronous and asynchronous content construction and revision by different writers working from different locations on a single document (Zhou et al., 2012) or on different items of a document without conflict (Abrams, 2019). Second, it has a simple writing interface that has most of the options available in standard word processing programs. Therefore, it would be easy to use for anyone acquainted with the use of a word processor (Brodahl et al., 2011). Third, the revision history function available in Google Docs contributes to more transparency among collaborators (Kessler et al., 2012). For example, erased content stays in saved drafts, displayed as crossed-out text. This option allows the instructor as well as other group members to examine each writer's contribution toward the final version of the text (Abrams, 2019). The framework of the treatment was adapted from Bikowski and Vithanage's (2016) CBCW Teaching Cycle that involved three stages: preparation, collaborative writing, and reflection.

\subsubsection{The Preparation Stage}

As Abrams (2019) points out, for writers to get maximum gains from $\mathrm{CBCW}$, they need to receive instruction and training. Therefore, using $\mathrm{CBCW}$ started with offering the participants two training sessions. The first session lasted 45 minutes and was taken in class where participants learned about collaborative writing; i.e., its meaning, advantages, and steps. As recommended by Bikowski and Vithanage (2016), rapport-building and trust-building activities should be carried out before groups start writing together. Therefore, the researcher led a discussion to reach an agreement with participants on rules for working in group, negotiating politely, listening to others' ideas, making a clear and direct point, considering each other's feelings, and managing time.

The second part of the training was a one-hour session given in a computer lab where participants learned how to use Google Docs to write collaboratively. A short video explaining how to use Google Docs was displayed, along with step-by-step instructions offered by the researcher. Additionally, an illustrative guide, prepared by the researcher on how to use Google Docs for collaborative writing, was shared with participants. Participants who did not have Gmail accounts were asked to create one and share the address with the researcher.

After the training was over, participants were divided into groups of three or four students. According to Dale (1997), dividing learners into groups based on their competency levels helps them to increase their confidence and to improve their contributions. Also, according to Storch and Aldosari (2013), collaboration happens more likely among groups with similar ability. Therefore, groups were formed by the researcher based on the scores of the pretest so that group members were homogenous in their writing skills. Three groups included three participants while three other groups included four participants.

\subsubsection{The Collaborative Writing Stage}

This stage included three processes: pre-writing, drafting, and rewriting.

\section{1) Pre-writing}

Every week all participants were assigned a topic to write an essay about. Participants used Google Docs to write their essays. Members of each group created a new Google Doc to use for writing their essay. They started with online brainstorming through the discussion feature embedded in the Google Docs application. They discussed the ideas, made decisions and filtered them, clustered, mapped, and outlined the ideas that would be used in the following writing stage.

\section{2) Drafting}

After participants agreed on the ideas, they started writing their essays. Using Google Docs allowed participants to use parallel-partitioned writing where group members worked on the same essay. More specifically, each member could work on a separate part of the essay, yet each member in a group could add to what other group members had written at any time. As such, participants collaboratively contributed to all features of the text: ideas, structure, mechanics, and organization synchronously or asynchronously. Group members wrote similar amounts of text and had the freedom to add to others' contributions, without changing them. 


\section{3) Rewriting}

After finishing their drafts, groups published them to the Google Docs discussion page of the whole class in order to receive feedback from the researcher as well as other participants. The researcher encouraged participants to read their colleagues' essays and give feedback. To enhance the review process, a checklist was created by the researcher and uploaded to the discussion page. This checklist included some questions to help other participants to revise the drafts and give recommendations for improvement. The researcher also gave advice for improving the essays. Students also used the feedback features available in Google Docs to ask for support from their colleagues and the researcher. Based on all these recommendations, each group modified their essay and published the final text on the discussion page. Google Docs also offered the researcher the opportunity to monitor the groups' composing and editing processes and allowed her to revert to previous versions of the texts.

\subsubsection{The Reflective Stage}

After publishing their finished essays, participants were asked to describe their opinion about the performance of their group members. Participants also responded to a self-assessment checklist regarding their own progress. They were also required to reflect on their collaborative writing experiences as well as their experiences using Google Docs. Some questions were given by the researcher to help them in the reflection process. Questions included: "Did you enjoy writing collaboratively?" "Do you think Google Docs was a useful tool for learning?" "How did using Google Docs help you in writing your essay?" and "Would you use Google Docs in any coming writing course?" Reflections and comments were posted on the Google Docs discussion page.

\section{Results}

Data were statistically analyzed for both writing quantity and quality. Wilcoxon Signed Ranks Test, a nonparametric statistical method, was adopted due to the small number of participants. The level of significance was set at the 0.05 level.

\subsection{Result for Writing Quantity}

Wilcoxon Signed Ranks test was used to examine the difference between participants' mean scores between the pretest and the posttest of writing quantity. See Table 1.

Table 1. Wilcoxon signed ranks test for the difference in the mean scores of the participants between the pretest and the posttest of writing quantity

\begin{tabular}{lccccc}
\hline & & N & Mean Rank & Sum of Ranks & Probability \\
\hline Pretest-Posttest & Negative Ranks & 5 & 12.50 & 62.50 & \\
& Positive Ranks & 16 & 10.53 & 168.50 & Non-significant \\
& Ties & 0 & & & \\
& Total & 21 & & & \\
\hline
\end{tabular}

As indicated in Table 1, Wilcoxon Signed Ranks test revealed that the difference between the mean scores of the participants between the pretest and the posttest of writing quantity was not significant $(\mathrm{T}=62.50, \mathrm{p}>0.05)$.

\subsection{Result for Writing Quality}

Wilcoxon Signed Ranks test was used to examine the difference between participants' mean scores between the pretest and the posttest of writing quality. See Table 2.

Table 2. Wilcoxon signed ranks test for the difference in the mean scores of the participants between the pretest and the posttest of writing quality

\begin{tabular}{lccccc}
\hline & & $\mathrm{N}$ & Mean Rank & Sum of Ranks & Probability \\
\hline Pretest-Posttest & Negative Ranks & 1 & 1.00 & 1.00 & \\
& Positive Ranks & 20 & 11.50 & 230.00 & Significant \\
& Ties & 0 & & & \\
& Total & 21 & & & \\
\hline
\end{tabular}

As indicated in Table 2, Wilcoxon Signed Ranks test revealed that the difference between the mean scores of the participants between the pretest and the posttest of writing quality was significant $(T=1.00, p<0.05)$. 


\section{Discussion}

The present study aimed to investigate the effect of CBCW on the quantity and quality of EFL students' writing. The first hypothesis stated that "a statistically significant difference would be found between the mean scores of participants between the pretest and the posttest of writing quantity." In order to test this hypothesis, Wilcoxon Signed Ranks test was used to compare participants' mean scores between the pretest and the posttest of writing quantity. No statistically significant difference appeared. Therefore, this hypothesis was rejected. This result agrees with the results of other studies which found that CBCW did not lead to the production of longer texts (e.g., Elola \& Oskoz, 2010; Villarreal \& Gil-Sarratea, 2019) and disagrees with the results of some other studies which found that writing collaboratively makes writers produce more content (e.g., Daskalogiannaki, 2012; Doult \& Walker, 2014; Mak \& Coniam, 2008; Mills \& Exley, 2014; Storch, 2011; Yim et al., 2017). A possible explanation for this result is the small number of participants $(\mathrm{N}=21)$. Therefore, the researcher suggests that this result may be attributed to little power, not to lack of treatment impact. She assumes that if the present study is replicated with a larger number of participants, a significant effect will appear for CBCW on EFL students' writing quantity.

The second hypothesis stated that "a statistically significant difference would be found between the mean scores of participants between the pretest and the posttest of writing quality." In order to test this hypothesis, Wilcoxon Signed Ranks test compared participants' mean scores between the pretest and the posttest of writing quality and showed a statistically significant difference. Therefore, the second hypothesis was accepted. This result agrees with the results of some studies which found that $\mathrm{CBCW}$ yielded the production of better quality texts (e.g., Abrams, 2019; Al-Shumaimeri, 2011; Arslan \& Șahin-Kizil, 2010; Bailey \& Judd, 2018; Beltrán, 2010; Daskalogiannaki, 2012; Dobao, 2012; Doult \& Walker, 2014; Kessler \& Bikowski, 2010; Mak \& Coniam, 2008; McDonough \& García-Fuentes, 2015; Mills \& Exley, 2014; Myers, 2014; Shukor \& Noordin, 2014; Strobl, 2014; Togatorop, 2015; Villarreal \& Gil-Sarratea, 2019; Wichadee, 2011; Yeh, 2014; Yim et al., 2017).

A possible explanation for this result is the positive effect of the collaboration process on writing quality. This explanation is confirmed by some studies (e.g., Jafari \& Ansari, 2012; Shehadeh, 2011) that found collaboration to improve the quality of writing. In this respect, some researchers pointed out that collaboration in writing leads to more correct grammar and lexis (Li \& Kim, 2016), improved content and organization (Shehadeh, 2011), a stronger reader-writer relationship (Kuteeva, 2011), increased sense of audience (Sun \& Chang, 2012), and better solutions to the linguistic problems writers usually encounter (Dobao, 2012). Moreover, collaboration forces student writers to share responsibility for the written product (Dobao, 2012), helps them acquire different writing skills (Mulligan \& Garofalo, 2011), evokes a positive sense of competition among them (Bikowski \& Vithanage, 2016), and enables them to recognize the weaknesses in their writing (Elola \& Oskoz, 2010).

Another possible explanation for this finding is the positive effect of technology use on participants' writing quality. This explanation finds support in many studies (e.g., AbuSeileek \& Abualsha'r, 2014; Hughes, Regan, \& Evmenova, 2019; Shintani, 2016). As proposed by some educators, computers help to unblock flow of ideas as well as increase students' motivation to write (Abdul Aziz \& Hoon, 2015; Taki \& Fardafshari, 2012). Moreover, social technologies promote new knowledge generation and content construction (Elola \& Oskoz, 2010). Newer technologies that allow many-to-many communication benefit writing by allowing more revision and feedback (Kessler et al., 2012) while producing, rather than after producing (Abdul Aziz \& Hoon, 2015). More particularly, cloud computing benefits writing development as proved in several studies (e.g., Limbu, 2012; Orehovački, 2011; Yim et al., 2014). According to Zheng, Lawrence, Warschauer, and Lin (2015), cloud-based technology can improve students' writing and engage them in fruitful interactions with readers. Among the different CBCW tools, the present study used Google Docs to provide an environment that helped for online collaboration. This application has been found to be effective for improving writing by many studies (e.g., Kessler et al., 2012; Suwantarathip \& Wichadee, 2014; Zhou et al., 2012) as it possesses some features that help in improving writing. For example, it helps learners to collaborate better than those using word processing applications (Suwantarathip \& Wichadee, 2014). Also, learners can view previous versions of the text and can find clear indications of which modifications were made by whom (Kessler et al., 2012). This might have enhanced participants' ability to produce better texts as each member's contribution to improve the quality of the text was visible to both the researcher and other group members.

A further explanation for this finding is the environment provided for writers during the treatment. $\mathrm{CBCW}$ tasks are believed to be particularly motivating for students who are reluctant to write individually (Bikowski \& Vithanage, 2016) as writing alone may be very stressful to many students who lack enough ideas or writing competency (Amir, Ismail, \& Hussin, 2010). CBCW could be beneficial for EFL writers as it offers them communicative opportunities to write in a friendly and engaging atmosphere that involves little limitations on space and time (Sun \& Chang, 2012). Therefore, CBCW may have improved participants' attitudes towards 
writing which might have led to improving the quality of their writing (Cahyono \& Mutiaraningrum, 2016; Hussin, Abdullah, Ismail, \& Yoke, 2015). A final explanation for this result is the use of reflection. As many studies (e.g., Amicucci, 2011; Kirk, 2017; Sharifi \& Hassaskhah, 2011; Yang, 2010) found, reflection affects writing positively. For Bikowski and Vithanage (2016), reflection assists learners in evaluating their written products in order to find out how well they wrote in addition to areas that need improvement.

\section{Conclusion, Recommendations, and Suggestions for Further Research}

Based on the results of the present study, the researcher concluded that $\mathrm{CBCW}$ can be used to improve the quality of essays written by EFL students. She recommended that: (1) cloud-based technology should be employed in EFL writing classes, (2) collaborative writing should be encouraged, particularly with reluctant writers, and (3) more attention should be directed towards improving EFL students' writing quantity and quality. Moreover, she suggested conducting research studies tackling: (1) a comparison between the impacts of face-to-face collaborative writing vs. CBCW on EFL students' writing performance, (2) the effect of $\mathrm{CBCW}$ on writing apprehension, and (3) the effect of $\mathrm{CBCW}$ on EFL writing quantity with a large research sample.

\section{References}

Abdul Aziz, M., \& Hoon, T. (2015). Impact of composing medium on the quality \& quantity of writing. Language \& Communication, 2(2), 157-168.

Abrams, Z. (2019). Collaborative writing \& text quality in Google Docs. Language Learning \& Technology, 23(2), 22-42.

AbuSeileek, A., \& Abualsha'r, A. (2014). Using peer computer-mediated corrective feedback to support EFL learners' writing. Language Learning \& Technology, 18(1), 76.

Al-Asmari, A. (2013). Investigation of writing strategies, writing apprehension, \& writing achievement among Saudi EFL-major students. International Education Studies, 6(11), 130-143. https://doi.org/10.5539/ies.v6n11p130

Al-Cattan, R. (2014). Integration of cloud computing \& Web2.0 collaboration technologies in e-learning. International Journal of Computer Trends \& Technology, 12(1), 46-55. https://doi.org/10.14445/22312803/IJCTT-V12P110

Al-Dahdouh, A., Osorio, A., \& Caires, S. (2015). Understanding knowledge network, learning \& connectivism. International Journal of Instructional Technology \& Distance Learning, 12(10), 3-21.

Al-Khairy, M. (2013). Saudi English-major undergraduates' academic writing problems: A Taif University perspective. English Language Teaching, 6(6), 1-12. https://doi.org/10.5539/elt.v6n6p1

Al-Mansour, N., \& Al-Shorman, R. (2014). The effect of an extensive reading program on the writing performance of Saudi EFL university students. International Journal of Linguistics, 6(2), 258-275. https://doi.org/10.5296/ijl.v6i2.5551

Al-Rabai, F. (2016). Factors underlying low achievement of Saudi EFL learners. International Journal of English Linguistics, 6(3), 17. https://doi.org/10.5539/ijel.v6n3p21

Al-Rashidi, O., \& Phan, H. (2015). Education context \& English teaching \& learning in the Kingdom of Saudi Arabia: An overview. English Language Teaching, 8(25), 33-44. https://doi.org/10.5539/elt.v8n5p33

Al-Samadani, H. (2010). The relationship between Saudi EFL students' writing competence, L1 writing proficiency, \& self-regulation. European Journal of Social Sciences, 16(1), 53-63.

Al-Samarraie, H., \& Saeed, N. (2018). A systematic review of cloud computing tools for collaborative learning: Opportunities \& challenges to the blended-learning environment. Computers \& Education, 124, 77-91. https://doi.org/10.1016/j.compedu.2018.05.016

Al-Saraj, T. (2014). Foreign language anxiety in female Arabs learning English: Case studies. Innovation in Language Learning \& Teaching, 8(3), 257-278. https://doi.org/10.1080/17501229.2013.837911

Al-Shumaimeri, Y. (2011). The effects of wikis on foreign language students writing performance. Procedia Social \& Behavioral Sciences, 28, 755-763. https://doi.org/10.1016/j.sbspro.2011.11.139

Al-Zain, H. (2019). The role of social networks in supporting collaborative e-learning based on Connectivism Theory among students of PNU. Turkish Online Journal of Distance Education, 20(2), 46-63. https://doi.org/10.17718/tojde.557736

Amicucci, A. (2011). Using reflection to promote students' writing process awareness. CEA Forum, 40(1), 
$34-56$.

Amir, Z., Ismail, K., \& Hussin, S. (2010). Blogs in language learning: Maximizing students' collaborative writing. Procedia Social \& Behavioral Sciences, 18, 537-543. https://doi.org/10.1016/j.sbspro.2011.05.079

Ansarimoghaddam, S., \& Bee, H. (2013). Co-constructing an essay: Collaborative writing in class \& on wiki. Language, Linguistics \& Literature, 19(1), 35-50.

Apple, K., Reis-Bergan, M., Adams, A., \& Saunders, G. (2011). Online tools to promote student collaboration. In D. Dunn, J. Wilson, J. Freeman, \& J. Stowell (Eds.), Getting connected: Best practices for technology enhanced teaching \& learning in high education (pp. 239-252). New York: Oxford University Press. https://doi.org/10.1093/acprof:osobl/9780199733187.003.0016

Arslan, R., \& Şahin-Kizil, A. (2010). How can the use of blog software facilitate the writing process of English language learners? Computer Assisted Language Learning, 23(3), 183-197. https://doi.org/10.1080/09588221.2010.486575

Aydin, Z., \& Yildiz, S. (2014). Using wikis to promote collaborative EFL writing. Language Learning \& Technology, 18(1), 160-180.

Bailey, D., \& Judd, C. (2018). The effects of online collaborative writing \& TOEIC writing test-preparation on L2 writing performance. The Journal of Asia TEFL, 15(2), 383-397. https://doi.org/10.18823/asiatefl.2018.15.2.8.383

Beltrán, A. (2010). EFL university learners working collaboratively with digital storyboards. Bogotá, Colombia: Distrital University.

Bikowski, D., \& Vithanage, R. (2016). Effects of web-based collaborative writing on individual L2 writing development. Language Learning \& Technology, 20(1), 79-99.

Bower, M., \& Richards, D. (2006). Collaborative learning: Some possibilities \& limitations for students \& teachers. Proceedings of the 23rd Annual Ascilite Conference: Who's learning? Whose technology? (pp. 79-89). Sydney: University of Sydney.

Brodahl, C., Hadjerrouit, S., \& Hansen, N. (2011). Collaborative writing with Web 2.0 technologies: Education students' perceptions. Journal of Information Technology Education: Innovations in Practice, 10, 73-103. https://doi.org/10.28945/1384

Cahyono, B., \& Mutiaraningrum, I. (2016). Indonesian EFL teachers' familiarity with \& opinion on the internet-based teaching of writing. English Language Teaching, 9(1), 199-208. https://doi.org/10.5539/elt.v9n1p199

Calvo, R., O’Rourke, S., Jones, J., Yacef, K., \& Reimann, P. (2011). Collaborative writing support tools on the cloud. IEEE Transactions on Learning Technologies, 4, 88-97. https://doi.org/10.1109/TLT.2010.43

Chu, S., \& Kennedy, D. (2011). Using online collaborative tools for groups to co-construct knowledge. Online Information Review, 35(4), 581-597. https://doi.org/10.1108/14684521111161945

Crossley, S., \& McNamara, D. (2016). Say more \& be more coherent: How text elaboration \& cohesion can increase writing quality. Journal of Writing Research, 7(3), 351-370. https://doi.org/10.17239/jowr-2016.07.03.02

Dale, H. (1997). Co-authoring in the classroom: Creating an environment for effective collaboration. Urbana, IL: The National Council of Teachers of English.

Daskalogiannaki, E. (2012). Developing \& assessing EFL students' writing skills via a class blog. Research Papers in Language Teaching \& Learning, 3(1), 269-292.

Dixson, M. (2016). Nonverbal immediacy behaviors \& online student engagement: Bringing past instructional research into the present virtual classroom. Communication Education, 66, 37-53. https://doi.org/10.1080/03634523.2016.1209222

Dobao, A. (2012). Collaborative writing tasks in the L2 classroom: Comparing group, pair, \& individual work. Journal of Second Language Writing, 21(1), 40-58. https://doi.org/10.1016/j.jslw.2011.12.002

Dooley, K., \& Sexton-Finck, L. (2017). A focus on collaboration: Fostering Australian screen production students' teamwork skills. Journal of Teaching \& Learning for Graduate Employability, 8(1), 74. https://doi.org/10.21153/jtlge2017vol8no1 art642

Doult, W., \& Walker, S. (2014). He's gone \& wrote over it: The use of wikis for collaborative report writing in a 
primary school classroom. International Journal of Primary, Elementary, \& Early Years Education, 42(6), 601-620. https://doi.org/10.1080/03004279.2012.752022

Duke, B., Harper, G., \& Johnston, M. (2013). Connectivism as a digital age learning theory. The International HETL Review, Special Issue, 4-13.

Elola, I., \& Oskoz, A. (2010). Collaborative writing: Fostering foreign language \& writing conventions development. Language Learning \& Technology, 14(3), 51-71.

Erkan, D., \& Saban, A. (2011). Writing performance relative to writing apprehension, self-efficacy in writing, \& attitudes towards writing: A correlational study in Turkish tertiary-level EFL. Asian EFL journal, 5(4), 164-192.

Faruk, S. (2013). English language teaching in Saudi Arabia: A world system perspective. Scientific Bulletin of the Politehnica University of Timişoara Transactions on Modern Languages, 12(1), 73-80.

Fung, Y. (2010). Collaborative writing features. RELC Journal, 41(1), 18-30. https://doi.org/10.1177/0033688210362610

Garrison, D. (2009). Communities of inquiry in online learning. In P. Rogers (Ed.), Encyclopedia of distance learning (2nd ed., pp. 352-355). Hershey, PA: IGI Global. https://doi.org/10.4018/978-1-60566-198-8.ch052

Goldie, J. (2016) Connectivism: A knowledge learning theory for the digital age? Medical Teacher, 38(10), 1064-1069. https://doi.org/10.3109/0142159X.2016.1173661

Grami, G. (2010). The effects of integrating peer feedback into university-level ESL writing curriculum: A comparative study in a Saudi context (Unpublished doctoral dissertation). Newcastle University.

Guoli, Z., \& Wanjun, L. (2010, February). The applied research of cloud computing platform architecture in the e-learning area. Paper presented at the 2nd International Conference on Computer \& Automation Engineering, Singapore.

Hadjerrouit, S. (2011). Collaborative writing approach to wikis: Design, implementation, \& evaluation. Issues in Informing Science \& Information Technology, 8, 431-449. https://doi.org/10.28945/1432

Hanko, G. (2016). Increasing competence through collaborative problem-solving: Using insight into social \& emotional factors in children's learning. New York, NY: Routledge.

Hughes, M., Regan, K., \& Evmenova, A. (2019). A computer-based graphic organizer with embedded self-regulated learning strategies to support student writing. Intervention in School \& Clinic 55(1), 13-22. https://doi.org/10.1177/1053451219833026

Hussin, S., Abdullah, M., Ismail, N., \& Yoke, S. (2015). The effects of CMC applications on ESL writing anxiety among postgraduate students. English Language Teaching, 8(9), 167-172. https://doi.org/10.5539/elt.v8n9p167

Jafari, N., \& Ansari, D. (2012). The effect of collaboration on Iranian EFL learners' writing accuracy. International Education Studies, 5(2), 125-131. https://doi.org/10.5539/ies.v5n2p125

Jahin, J. (2012). The effect of peer reviewing on writing apprehension \& essay writing ability of prospective EFL teachers. Australian Journal of Teacher Education, 37(11), 60-84. https://doi.org/10.14221/ajte.2012v37n11.3

Javid, C., Farooq, U., \& Umer, M. (2013). An Investigation of Saudi EFL learners' writing problems: A case study along gender-lines. Kashmir Journal of Language Research, 16(1), 179-203.

Jewell, J., \& Malecki, C. (2005). The utility of CBM written language indices: An investigation of production-dependent, production-independent, \& accurate-production scores. School Psychology Review, 34(1), 27-44.

Kessler, G., \& Bikowski, D. (2010). Developing collaborative autonomous language learning abilities in computer mediated language learning: Attention to meaning among students in wiki space. Computer Assisted Language Learning, 23, 41-58. https://doi.org/10.1080/09588220903467335

Kessler, G., Bikowski, D., \& Boggs, J. (2012). Collaborative writing among second language learners in academic web-based projects. Language Learning \& Technology, 16(1), 91-109.

Khan, I. (2011). Learning difficulties in English: Diagnosis \& pedagogy in Saudi Arabia. Educational Research, $2(7), 1248-1257$. 
Kirk, S. (2017). Waves of reflection: Seeing knowledges in academic writing. Proceedings of the 2015 BALEAP Conference. Reading: Garnet Publishing.

Kloepper, L. (2017). Collaboration, not oration: Tips for engaging students \& promoting active learning in large classrooms. The Journal of the Acoustical Society of America, 141(5), 4018-4019. https://doi.org/10.1121/1.4989243

Kormos, J. (2011). Task complexity \& linguistic \& discourse features of narrative writing performance. Journal of Second Language Writing, 20, 148-161. https://doi.org/10.1016/j.jslw.2011.02.001

Kuteeva, M. (2011). Wikis \& academic writing: Changing the writer-reader relationship. English for Specific Purposes, 30(1), 44-57. https://doi.org/10.1016/j.esp.2010.04.007

Lee, L. (2010). Exploring wiki-mediated collaborative writing: A case study in an elementary Spanish course. CALICO Journal, 27(2), 260-276. https://doi.org/10.11139/cj.27.2.260-276

Li, M., \& Kim, D. (2016). One wiki, two groups: Dynamic interactions across ESL collaborative writing tasks. Journal of Second Language Writing, 31, 25-42. https://doi.org/10.1016/j.jslw.2016.01.002

Limbu, M. (2012). Teaching writing in the cloud: Networked writing communities in the culturally \& linguistically diverse classrooms. Journal of Global Literacies, Technologies, \& Emerging Pedagogies, 1(1), $1-20$.

Lin, C., Yu, W., \& Wang, J. (2014). Cloud collaboration: Cloud-based instruction for business writing class. World Journal of Education, 4(6), 9-15. https://doi.org/10.5430/wje.v4n6p9

Liou, H., \& Lee, S. (2013). How wiki-based writing influences college students' collaborative \& individual composing products, processes, \& learners' perceptions. In B. Zou (Ed.), Explorations of language teaching \& learning with computational assistance. Hershey, PA: IGI Global. https://doi.org/10.4018/ijcallt.2011010104

Liu, M., Liu, L., \& Liu, L. (2018). Group awareness increases student engagement in online collaborative writing. The Internet \& Higher Education, 38, 1-8. https://doi.org/10.1016/j.iheduc.2018.04.001

Mahmoud, M. (2014). The effectiveness of using the cooperative language learning approach to enhance EFL writing skills among Saudi university students. Journal of Language Teaching \& Research, 5(3), 616-625. https://doi.org/10.4304/jltr.5.3.616-625

Mak, B., \& Coniam, D. (2008). Using wikis to enhance \& develop writing skills among secondary school students in Hong Kong. System, 36(3), 437-455. https://doi.org/10.1016/j.system.2008.02.004

Mattar, J. (2018). Constructivism \& connectivism in education technology: Active, situated, authentic, experiential, \& anchored learning. Revista Iberoamericana De Educación a Distancia, 21(2), 201-217. https://doi.org/10.5944/ried.21.2.20055

McDonough, K., \& García-Fuentes, C. (2015). The effect of writing task \& task conditions on Colombian EFL learners' language use. TESL Canada Journal, 32, 67-79. https://doi.org/10.18806/tesl.v32i2.1208

McGerald, J., \& Nidds, J. (1997). How functional is portfolio assessment anyway? The Educational Digest, $62(5), 47-50$.

McMaster, K., \& Campbell, H. (2007). Technical features of new \& existing CBM writing measures within \& across grades (Technical Report No. 7). Minneapolis, MN: Research Institute on Progress Monitoring.

Mills, K., \& Exley, B. (2014). Time, space, \& text in the elementary school digital writing classroom. Written Communication, 31(4), 434-469. https://doi.org/10.1177/0741088314542757

Mulligan, C., \& Garofalo, R. (2011). A collaborative writing approach: Methodology \& student assessment. The Language Teacher, 35(3), 5-10.

Myers, J. (2014). Digital conversations: Taking reader response into the 21st century. English in Texas, 44(1), 59-65.

National Assessment of Educational Progress. (2011). The nation's report card: Writing 2011. US Department of Education: National Center for Education Statistics.

Orehovački, T. (2011). Perceived quality of cloud based applications for collaborative writing. In J. Pokorny et al. (Eds.), Information systems development. New York, NY: Springer. https://doi.org/10.1007/978-1-4419-9790-6_46 
Ozturk, H. (2015). Examining value change in MOOCs in the scope of Connectivism \& Open Educational Resources movement. The International Review of Research in Open \& Distributed Learning, 16(5). https://doi.org/10.19173/irrodl.v16i5.2027

Ramírez, Y. (2013). Writing skill enhancement when creating narrative texts through the use of collaborative writing \& the Storybird Web 2.0 tool. Colombia Applied Linguistics Journal, 15(2), 166-183. https://doi.org/10.14483/udistrital.jour.calj.2013.2.a02

Rank, P. (2018). Using Connectivism theory in the classroom. NACTA Journal, 62(1), 102-103.

Remesal, A., \& Colomina, R. (2013). Social presence \& online collaborative small group work: A $\begin{array}{lllll}\text { socioconstructivist account. Computers \& Education, } & 60(1), \quad 357-367 .\end{array}$ https://doi.org/10.1016/j.compedu.2012.07.009

Révész, A., Kourtali, N., \& Mazgutova, D. (2017). Effects of task complexity on L2 writing behaviors \& linguistic complexity. Language Learning, 67, 208-241. https://doi.org/10.1111/lang.12205

Rosário, P., Högemann, J., Núñez, J., Vallejo, G., Cunha, J., Oliveira, V., ... \& Rodrigues, C. (2017). Writing week journals to improve the writing quality of fourth-graders' compositions. Reading \& Writing, 30(5), 1009-1032. https://doi.org/10.1007/s11145-016-9710-4

Schoor, C., Narciss, S., \& Körndle, H. (2015). Regulation during cooperative \& collaborative learning: A theory-based review of terms \& concepts. Educational Psychologist, 50(2), 97-119. https://doi.org/10.1080/00461520.2015.1038540

Sharifi, A., \& Hassaskhah, J. (2011). The role of portfolio assessment \& reflection in process writing. Asian EFL Journal, 13(1), 192-229.

Shehadeh, A. (2011). Effects \& student perceptions of collaborative writing in L2. Journal of Second Language Writing, 20(4), 286-305. https://doi.org/10.1016/j.jslw.2011.05.010

Shintani, N. (2016). The effects of computer-mediated synchronous \& asynchronous direct corrective feedback on writing: A case study. Computer Assisted Language Learning, 29(3), 517-538. https://doi.org/10.1080/09588221.2014.993400

Short, J., Williams, E., \& Christie, B. (1976). The social psychology of telecommunications. London: John Wiley $\&$ Sons.

Shukor, S., \& Noordin, N. (2014). Effects of Facebook collaborative writing groups on ESL undergraduates' writing performance. International Journal of English Language Education, 2(2), 89-99. https://doi.org/10.5296/ijele.v2i2.5868

Smith, S., \& Caruso, J. (2010). The ECAR study of undergraduate students \& information technology. Loisville, CO: Educause Center for Applied Research.

Storch, N. (2011). Collaborative writing in L2 contexts: Processes, outcomes, \& future directions. Annual Review of Applied Linguistics, 31, 275-288. https://doi.org/10.1017/S0267190511000079

Storch, N. (2013). Collaborative writing in L2 classrooms. Bristol, UK: Multilingual Matters. https://doi.org/10.21832/9781847699954

Storch, N., \& Aldosari, A. (2013). Pairing learners in pair work activity. Language Teaching Research, 17, 31-48. https://doi.org/10.1177/1362168812457530

Strobl, C. (2014). Affordances of Web 2.0 technologies for collaborative advanced writing in a foreign language. CALICO Journal, 31(1), 1-18. https://doi.org/10.11139/cj.31.1.1-18

Strobl, C. (2015). Learning to think \& write together: Collaborative synthesis writing, supported by a script \& a video-based model. In M. Deane, \& T. Guasch (Eds.), Learning \& teaching writing online: Strategies for success (pp. 69-95). Leiden, Holland: BRILL. https://doi.org/10.1163/9789004290846_006

Sun, Y., \& Chang, Y. (2012). Blogging to learn: Becoming EFL academic writers through collaborative dialogues. Language Learning \& Technology, 16(1), 43-61.

Suwantarathip, O., \& Wichadee, S. (2014). The effects of collaborative writing activity using Google Docs on students' writing abilities. Turkish Online Journal of Educational Technology, 13(2), 148-156.

Taki, S., \& Fardafshari, E. (2012). Weblog-based collaborative learning: Iranian EFL learners' writing skill \& motivation. International Journal of Linguistics, 4(2), 412-429. https://doi.org/10.5296/ijl.v4i2.1663 
Togatorop, E. (2015). Teaching writing with a web based collaborative learning. International Journal of Economics \& Financial Issues, 5, 247-256.

Vas, R., Weber, C., \& Gkoumas, D. (2018). Implementing Connectivism by semantic technologies for self-directed learning. International Journal of Manpower, 39(8), 1032-1046. https://doi.org/10.1108/IJM-10-2018-0330

Villarreal, I., \& Gil-Sarratea, N. (2019). The effect of collaborative writing in an EFL secondary setting. Language Teaching Research. https://doi.org/10.1177/1362168819829017

Vygotsky, L. (1978). Mind in society. Cambridge: Harvard University Press.

Wang, D. (2016). How people write together now: Exploring \& supporting today's computer-supported collaborative writing. Proceedings of the 19th ACM Conference on Computer Supported Cooperative Work \& Social Computing Companion (pp. 175-179). New York, NY: ACM. https://doi.org/10.1145/2818052.2874352

Warschauer, M. (2010). New tools for teaching writing. Language Learning \& Technology, 14(1), 3-8.

Warschauer, M. (2011). Learning in the cloud: How (\& why) to transform schools with digital media. New York, NY: Teachers College, Columbia University.

Wei, J., Seedorf, S., Lowry, P., Thum, C., \& Schulze, T. (2017). How increased social presence through co-browsing influences user engagement in collaborative online shopping. Electronic Commerce Research \& Applications, 24, 84-99. https://doi.org/10.1016/j.elerap.2017.07.002

Wichadee, S. (2011). Using wikis to develop summary writing abilities of students in an EFL class. Journal of College Teaching \& Learning, 7(12), 5-10. https://doi.org/10.19030/tlc.v7i12.951

Yang, Y. (2010). Students' reflection on online self-correction \& peer review to improve writing. Computers \& Education, 55(3), 1202-1210. https://doi.org/10.1016/j.compedu.2010.05.017

Yeh, H. (2014). Exploring how collaborative dialogues facilitate synchronous collaborative writing. Language Learning \& Technology, 18(1), 23-37.

Yeh, S., Lo, J., \& Huang, J. (2011). Scaffolding collaborative technical writing with procedural facilitation \& synchronous discussion. Computer-Supported Collaborative Learning, 6, 397-419. https://doi.org/10.1007/s11412-011-9117-9

Yim, S., \& Warschauer, M. (2019). Students initiating feedback: The potential of social media. In K. Hyland, \& F. Hyland (Eds.), Feedback in second language writing: Contexts \& issues (pp. 285-303). Cambridge: Cambridge University Press. https://doi.org/10.1017/9781108635547.017

Yim, S., \& Warschauer, M. (2017). Web-based collaborative writing in L2 contexts: Methodological insights from text mining. Language Learning \& Technology, 21(1), 146-165.

Yim, S., Wang, D., Olson, J., Vu, V., \& Warschauer, M. (2017). Synchronous writing in the classroom: Undergraduates' collaborative practices \& their impact on text quality, quantity, \& style. In Proceedings of the Conference on Computer Supported Cooperative Work, CSCW, February 25-March 1, 2017, Portland, OR, USA. https://doi.org/10.1145/2998181.2998356

Yim, S., Warschauer, M., Zheng, B., \& Lawrence, J. (2014). Cloud-based collaborative writing \& the common core standards. Journal of Adolescent \& Adult Literacy, 58(3), 243-254. https://doi.org/10.1002/jaal.345

Zheng, B., Lawrence, J., Warschauer, M., \& Lin, C. (2015). Middle school students' writing \& feedback in a cloud-based classroom environment. Technology, Knowledge, \& Learning, 20(2), 201-229. https://doi.org/10.1007/s10758-014-9239-z

Zhou, W., Simpson, E., \& Domizi, D. (2012). Google Docs in an out-of-class collaborative writing activity. International Journal of Teaching \& Learning in Higher Education, 24(3), 359-375.

Zurita, G., Baloian, N., \& Frez, J. (2014). Using the cloud to develop applications supporting geo-collaborative situated learning. Future Generation Computer Systems, 34, 124-137. https://doi.org/10.1016/j.future.2013.10.007 


\section{Copyrights}

Copyright for this article is retained by the author(s), with first publication rights granted to the journal.

This is an open-access article distributed under the terms and conditions of the Creative Commons Attribution license (http://creativecommons.org/licenses/by/4.0/). 